\title{
(2) OPEN ACCESS \\ Congenital contractural arachnodactyly suspected by abnormally long extremities by fetal ultrasound
}

\author{
Ryuta Miyake, Mayuko Ichikawa, Katsuhiko Naruse
}

OB/GYN, Nara Medical University Hospital, Kashihara, Japan

Correspondence to Dr Ryuta Miyake; ryuta-miyake@naramed-u.ac.jp

Accepted 8 February 2021

Check for updates

(c) BMJ Publishing Group Limited 2021. Re-use permitted under CC BY-NC. No commercial re-use. See rights and permissions. Published by BMJ.

To cite: Miyake $\mathrm{R}$ Ichikawa M, Naruse K. BM Case Rep 2021:14:e237904. doi:10.1136/bcr-2020237904

\section{SUMMARY}

Congenital contractural arachnodactyly (CCA) is a rare disease with the clinical features of limited extension of multiple joints, arachnodactyly, camptodactyly, thin and long extremities, and so on. In the point of long extremities, CCA resembles Marfan syndrome (MFS). CCA is easily differentiated from MFS after birth due to the flexion of multiple joints, including elbows, knees, hips and fingers. During the fetal period, observation of arachnodactyly and folded fingers by fetal ultrasound is the means of differential diagnosis between these two diseases. We report on a case of CCA diagnosed with prenatal symptoms of long extremities, and introduced physiotherapy in early childhood for a better physical prognosis.

\section{BACKGROUND}

Congenital contractural arachnodactyly (CCA) was first reported in 1971 by Beals and $\mathrm{Hecht}^{1}$ and, thus, called 'Beals and Hecht syndrome' or 'Beals syndrome'. The clinical features are limited extension of multiple joints, arachnodactyly, camptodactyly, thin and long extremities, bowed long bones, crumpled ears, scoliosis, adducted thumb and so on. ${ }^{2}$ CCA occurs because of fibrillin 2 (FBN2) gene mutation. The prognosis is typically not poor, unless there are severe cardiovascular complications. In terms of physical prognosis, physiotherapy from early childhood increases joint mobility and lessens muscle hypoplasia. ${ }^{2}$

\section{CASE PRESENTATION}

A woman in her 30s, gravida 2, para 1, live birth 1 , was seen in our hospital at 36 weeks of pregnancy due to fetal ultrasound abnormality. Her 20-month-old child has no congenital anomalies or developmental disorders. The patient had no medical history and no family history of cardiovascular disease, such as aortic dissection and aortic aneurysm. The patient has never smoked a cigarette and not consumed alcohol. She had taken multivitamin supplements from the first trimester of pregnancy, including folic acid and vitamin $\mathrm{B}$. She got spontaneous pregnancy and the expected delivery date was determined from the last menstrual period matched with ultrasound finding. The pregnancy was initially uncomplicated; at 31 weeks of pregnancy the fetal ultrasound showed the femur length (FL) to be $58 \mathrm{~mm}$, which was still considered acceptable. After 33 weeks of pregnancy the FL became longer than the average; the FL was $68 \mathrm{~mm}$ (+2.7 SD on Japan Society for Ultrasound in Medicine formula) at 33 weeks, $72 \mathrm{~mm}(+2.9 \mathrm{SD})$ at 35 weeks and $75 \mathrm{~mm}(+3.0 \mathrm{SD})$ at 36 weeks (figure 1$)$. The patient referred to our hospital at 36 weeks and 5 days; the fetal ultrasound (figure 2) showed abnormally long extremity bones. The FL was 77.9 $\mathrm{mm}$ (+3.7 SD), the tibia was $70.0 \mathrm{~mm}(+4.1 \mathrm{SD})$, the fibula was $71.9 \mathrm{~mm}(+5.4 \mathrm{SD})$, the humerus was $70.0 \mathrm{~mm}(+4.6 \mathrm{SD})$, the radius was $65.4 \mathrm{~mm}$ $(+5.4 \mathrm{SD})$ and the ulna was $73.2 \mathrm{~mm}(+6.6 \mathrm{SD})$, and they were curved in a bow shape. The length of the finger bones could not be measured because the fingers were folded. The amount of amniotic fluid was within the normal range and no other major anomalies, including that of the cardiovascular system, were detected.

\section{DIFFERENTIAL DIAGNOSIS}

We suspected CCA and Marfan syndrome (MFS) due to the long extremity bones. The long extremity is a common feature of CCA and MFS, but the joint contracture and arachnodactyly are only seen in CCA. CCA is easily distinguished from MFS by observing the condition of the joints and hands after birth. The distinguishing features in the fetal period are camptodactyly and folded fingers. ${ }^{3}$ In the reported case by Kölble et $a l,{ }^{4}$ whose father has CCA and was genetically diagnosed after birth, pes adductus, contractures of the elbows, camptodactyly and moderately deformed ears were found in fetal ultrasound. In contrast to MFS, patients with CCA rarely have the complications of aortic aneurysm or ectopia lentis.

By the fetal ultrasound findings, respectively, syphilis could be suspected by bowed bones, trisomy 18 by overlapped fingers, Achard syndrome

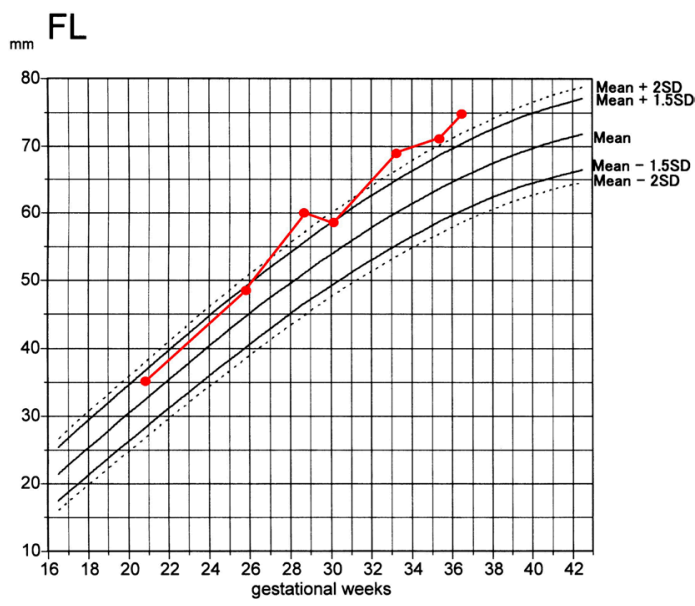

Figure 1 Regression curve of femur length and gestational weeks in Japanese fetus. $\mathrm{FL}$, femur length. 

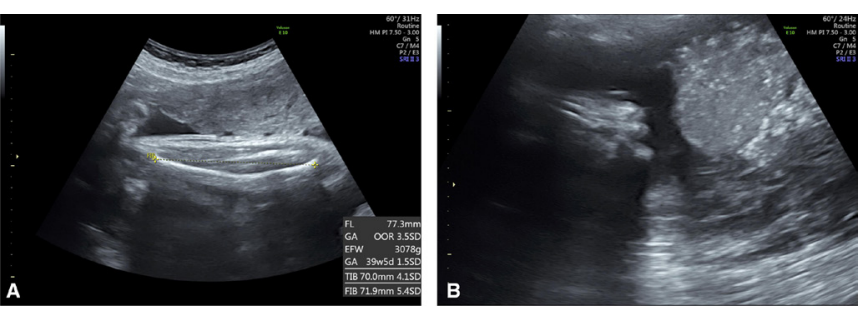

Figure 2 Fetal ultrasound at 36 weeks of gestation. (A) The length of right tibia is $70.0 \mathrm{~mm}(+4.1 \mathrm{SD})$. (B) The left fingers are folded.

by arachnodactyly, VACTERL by scoliosis and distal arthrogryptosis by multiple joint contractures.

\section{OUTCOME AND FOLLOW-UP}

On 39 weeks and 1 day of pregnancy, the patient gave birth to a female neonate by spontaneous vaginal delivery. Infant's birth weight was $3100 \mathrm{~g}$, and the Apgar scores were 9 at $1 \mathrm{~min}$ and 10 at $5 \mathrm{~min}$. The baby had crumpled ears, long extremities, limited extension of the hips, knees and elbow joints, arachnodactyly, camptodactyly, adducted thumb, and scoliosis (figure 3). The clinical features were matched to the characteristic of CCA. The neonate received physiotherapy from day 3. In the admission period, the neonate received an automated auditory brainstem response test, eye fundus examination, and brain and cardiac ultrasounds, which revealed no other complications. At day 4, X-rays showed bowed long bones and scoliosis (figure 4). The neonate was discharged from our hospital at day 12 .

Genome sequencing by next generation sequencer did not detect abnormal variant in genetic connective tissue disease gene panel (HCTDv4) including FBN2 gene.

The prognosis of CCA is typically not poor, unless there are severe cardiovascular complications. In terms of physical prognosis, physiotherapy from early childhood increases joint mobility and lessens muscle hypoplasia. ${ }^{2}$ In some patients, scoliosis is progressive and requires surgical treatment, which severely restricts the physical prognosis. Routine physical examination for spinal deformities and early intervention for scoliosis can prevent morbidity later in life. In Japan, CCA cases are reported in the orthopaedics societies and the age of diagnosis ranges between 18 months and 15 years. ${ }^{5}$ The diagnosis during the fetal period through ultrasound, or soon after birth, is essential for early intervention to improve the physical prognosis.

\section{DISCUSSION}

In this case, we suspected CCA and MFS by long extremities and bowed long bones prenatally.
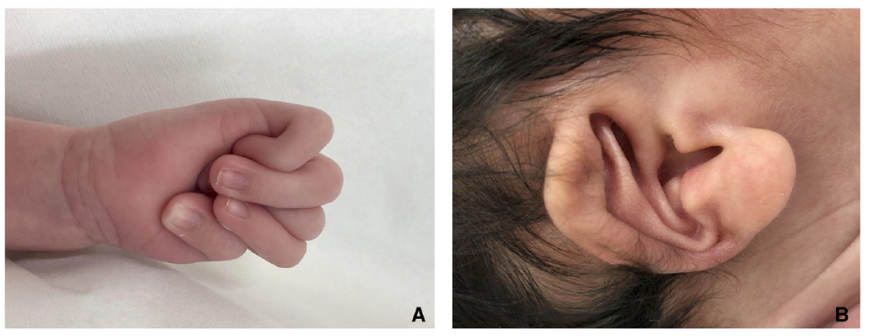

Figure 3 Pictures of the baby after birth. (A) The baby holds her hands tightly. The index finger and ring finger are folded over the middle finger. The thumb is adducted. (B) The baby's ear is crumpled. All photographs are provided after written informed consent by the patient's mother.
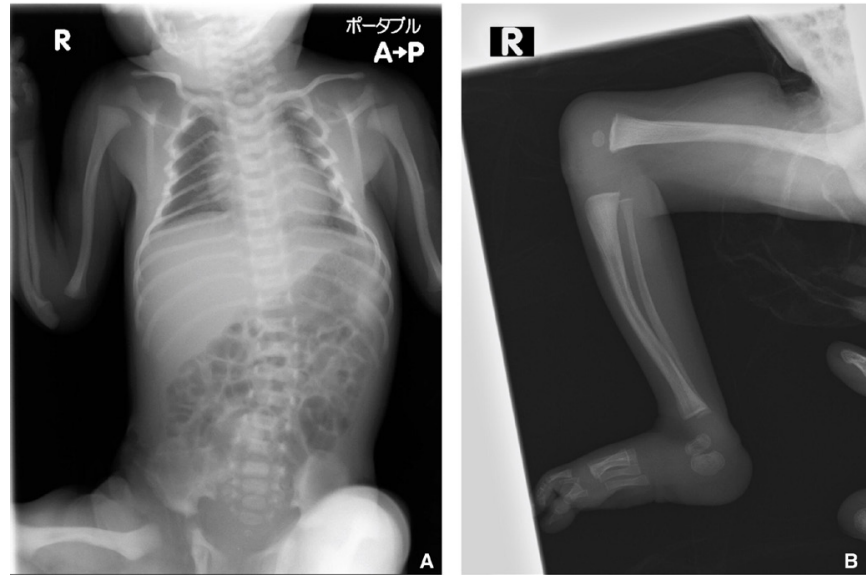

Figure 4 The X-ray of the baby on day 4. (A) The baby has scoliosis and her humerus is bowed. (B) The tibia is bowed which resembles the one shown in fetal ultrasound.

It is believed that the first case of CCA was reported by Marfan in 1896. The case Beals and Hecht reported was a 5-year-old girl with limited knee and elbow joints extension, followed by the complication of scoliosis, but the patient never developed cardiovascular and ocular complications. In this case, arachnodactyly, camptodactyly, limited extension of the elbow, knee and hip joints, crumpled ear, adducted thumb, scoliosis, and bowed long bones are matched to the clinical features of CCA.

CCA and MFS have the same clinical features as long extremities and bowed long bones. CCA and MFS are caused by fibrillin protein abnormalities. CCA is caused by a deficit in the FBN2 gene, which is mapped on 5q23-31. Previously, constitutional interstitial deletion of chromosome $5(\mathrm{q} 15 \mathrm{q} 31)$ or $5(\mathrm{q} 23 \mathrm{q} 31)$ patients were reported and they have the same clinical features as CCA. ${ }^{6}$ On the other hand, MFS is caused by FBN1 gene mutation mapped on chromosome $15 \mathrm{q} 15-21$. Both mutations result in errors in fibrillin production; fibrillin is composed of extracellular filaments and is distributed throughout the whole body, found in fascia, tendons and blood vessels. The FBN2 gene mutation is detected in $27 \%-43 \%$ of patients with CCA, ${ }^{78}$ and the maximum lod score is $6.2(\theta=0.005 ; 95 \% \mathrm{CI}) .^{9}$ In this case, genome sequencing revealed no abnormality in FBN2 gene region. Because of the low detection rate of FBN2 gene mutation in patients with CCA, this result does not deny the clinical diagnosis of CCA.

The long extremity is a common feature of CCA and MFS, but the joint contracture and arachnodactyly are only seen in CCA. CCA is easily distinguished from MFS by observing the condition of the joints and hands after birth. The distinguishing features in the fetal period are camptodactyly and folded fingers. ${ }^{3}$ Cardiovascular complications and ectopia lentis are characteristic

\section{Learning points}

- If long extremities and bowed long bones are seen in fetal ultrasound, congenital contractural arachnodactyly, in addition to Marfan syndrome, should come to mind.

- The distinguishing features in the fetal period are camptodactyly and folded fingers.

- Physiotherapy should be started from early childhood to increase joint mobility and lessen muscle hypoplasia, and have better physical prognosis. 
symptoms of MFS. Cardiovascular complications in CCA include mitral valve prolapse, atrial septal defects, ventricular septal defects ${ }^{10-12}$ and transient cardiomyopathy, ${ }^{13}$ with dilated cardiomyopathy, ${ }^{14}$ rarely reported in Japan. In CCA, 20\% of patients have heterotropia as an ophthalmological complication, ${ }^{10}$ and blue sclerae, glaucoma optic disc cupping, partial coloboma of the lens and abnormal ciliary body morphology have also been reported. In this case, cardiovascular and ophthalmological diseases were not present.

Contributors Concept and design-RM, MI and KN. Data analysis—RM and MI. Writing (original draft)—RM. Writing (review and editing)—RM and KN.

Funding The authors have not declared a specific grant for this research from any funding agency in the public, commercial or not-for-profit sectors.

\section{Competing interests None declared.}

Patient consent for publication Parental/guardian consent obtained.

Provenance and peer review Not commissioned; externally peer reviewed.

Open access This is an open access article distributed in accordance with the Creative Commons Attribution Non Commercial (CC BY-NC 4.0) license, which permits others to distribute, remix, adapt, build upon this work non-commercially, and license their derivative works on different terms, provided the original work is properly cited and the use is non-commercial. See: http://creativecommons.org/ licenses/by-nc/4.0/.

\section{REFERENCES}

1 Beals RK, Hecht F. Congenital contractural arachnodactyly. A heritable disorder of connective tissue. J Bone Joint Surg Am 1971;53:987-93.
2 Viljoen D. Congenital contractural arachnodactyly (Beals syndrome). J Med Genet 1994:31:640-3.

3 Inbar-Feigenberg M, Meirowitz N, Nanda D, et al. Beals syndrome (congenital contractural arachnodactyly): prenatal ultrasound findings and molecular analysis Ultrasound Obstet Gynecol 2014;44:486-90.

4 Kölble N, Wisser J, Babcock D, et al. Prenatal ultrasound findings in a fetus with congenital contractural arachnodactyly. Ultrasound Obstet Gynecol 2002;20:395-9.

5 Miyazaki Y, Sakamoto H. 膝関節伸展障害をきたしたCongential Contractual Arachnodactylyの一例[in Japanese]. Orthop Traumatol Surg Res 2002;3:625-8.

6 Courtens W, Tjalma W, Messiaen L, et al. Prenatal diagnosis of a constitutional interstitial deletion of chromosome 5 (q15q31.1) presenting with features of congenital contractural arachnodactyly. Am J Med Genet 1998;77:188-97.

7 Callewaert BL, Loeys BL, Ficcadenti A, et al. Comprehensive clinical and molecular assessment of 32 probands with congenital contractural arachnodactyly: report of 14 novel mutations and review of the literature. Hum Mutat 2009:30:334-41.

8 Nishimura A, Sakai H, Ikegawa S, et al. Fbn2, FBN1, TGFBR1, and Tgfbr2 analyses in congenital contractural arachnodactyly. Am J Med Genet A 2007;143A:694-8.

9 Tsipouras P, Del Mastro R, Sarfarazi M, et al. Genetic linkage of the Marfan syndrome, ectopia lentis, and congenital contractural arachnodactyly to the fibrillin genes on chromosomes 15 and 5. The International Marfan syndrome Collaborative study. $N$ Engl J Med 1992;326:905-9.

10 Tunçbilek E, Alanay Y. Congenital contractural arachnodactyly (Beals syndrome). Orphanet J Rare Dis 2006;1:20.

11 Anderson RA, Koch S, Camerini-Otero RD. Cardiovascular findings in congenital contractural arachnodactyly: report of an affected kindred. Am J Med Genet 1984;18:265-71

12 Bell RE, Wheller JJ. Cardiac defects in a patient with congenital contractural arachnodactyly. South Med J 1985;78:742-3.

13 Tae M, Atsushi W, Makoto M. Transient cardiomyopathy in a patient with congenital contractural arachnodactyly (Beals syndrome). J Nippon Med Sch 2006;5:285-8.

14 Hiroki Y, Masaru H, Norifumi T. Congenital contractural arachnodactyly without FBN1 or FBN2 gene mutations complicated by dilated cardiomyopathy. Intern Med 2015:10:1237-41.

Copyright 2021 BMJ Publishing Group. All rights reserved. For permission to reuse any of this content visit

https://www.bmj.com/company/products-services/rights-and-licensing/permissions/

BMJ Case Report Fellows may re-use this article for personal use and teaching without any further permission.

Become a Fellow of BMJ Case Reports today and you can:

- Submit as many cases as you like

- Enjoy fast sympathetic peer review and rapid publication of accepted articles

- Access all the published articles

Re-use any of the published material for personal use and teaching without further permission

Customer Service

If you have any further queries about your subscription, please contact our customer services team on +44 (0) 2071111105 or via email at support@bmj.com.

Visit casereports.bmj.com for more articles like this and to become a Fellow 